Hal $36-43$

\title{
PENINGKATAN KEMAMPUAN BERPIKIR KREATIF DAN SELF- EFFICACY SISWA MELALUI PENDEKATAN PEMBELAJARAN OPEN-ENDED
}

\author{
Laili Habibah Pasaribu, M.Pd', Suriyani,S.Pd.I., M.Pd², Masitah, M.Pd ${ }^{3}$
}

\author{
Program Studi Pendidikan Matematika, STKIP Labuhanbatu,JIn. SM. Raja No. 126A, KM, 3.5 Aek Tapa, Rantauprapat \\ Email: 1laili.habibah.pasaribu@gmail.com,2suryani.jahwa@yahoo.com
}

Diterima (April 2018) dan disetujui (Mei 2018)

\begin{abstract}
Abstrak
Kegiatan penelitian ini difokuskan pada peningkatan kemampuan berpikir kreatif dan Self-Efficacy matematis siswa yang diajar dengan menggunakan pendekatan Open Ended di MTs Negeri Rantauprapat. Penelitian ini dilaksanakan di MTs Negeri Rantauprapat. Jenis penelitian yang digunakan adalah kuasi eksperimen dengan desain kelompok kontrol non-ekivalen. Populasi dalam penelitian ini terdiri dari seluruh siswa kelas VIII melalui teknik Purposive Sampling. Instrumen yang digunakan terdiri dari tes kemampuan awal matematika, tes kemampuan berpikir kreatif, dan angket Self-Efficacy. Hasil penelitian menunjukkan bahwa (1) peningkatan kemampuan berpikir kreatif siswa yang diajar menggunakan pembelajaran matematika dengan pendekatan Open-Ended lebih baik daripada yang diajar dengan pembelajaran konvensional, (2) peningkatan Self Efficacy siswa yang diajar menggunakan pembelajaran matematika dengan pendekatan Open-Ended lebih baik daripada yang diajar dengan pembelajaran konvensional, (3) tidak terdapat interaksi antara pendekatan pembelajaran dengan kemampuan awal matematika siswa terhadap peningkatan kemampuan berpikir kreatif siswa, dan (4) tidak terdapat interaksi antara pendekatan pembelajaran dengan kemampuan awal matematika siswa terhadap peningkatan Self Efficacy siswa. Berdasarkan temuan penelitian pendekatan Open-Ended dapat direkomendasikan menjadi salah satu pendekatan pembelajaran yang digunakan di sekolah utamanya untuk mencapai kompetensi berpikir kreatif dan Self Efficacy.
\end{abstract}

Kata Kunci: Kemampuan Berpikir Kreatif, Self-Efficacy, Pendekatan Open Ended 


\section{PENDAHULUAN}

Melihat pentingnya matematika dipelajari maka tidak salah jika proses pembelajaran matematika di kelas menjadi perhatian penting oleh para pelaku pendidikan, khususnya seorang guru. Namun kenyataan di lapangan menunjukkan bahwa aktivitas dan kemampuan matematika siswa belum optimal. Aktivitas belajar siswa yang belum optimal terlihat dari sikap ketergantungan siswa terhadap guru dalam proses pembelajaran dan minat siswa untuk mengerjakan latihan baik di sekolah maupun di rumah, sedangkan kemampuan matematika siswa yang belum optimal dapat dilihat dari prestasi siswa baik di kelas maupun dalam kompetisi-kompetisi matematika tingkat lokal, nasional, dan internasional. Matematika sering dianggap sebagai mata pelajaran yang menjenuhkan dan sulit bagi siswa. Hal ini berakibat pada rendahnya hasil belajar siswa. Padahal mau tidak mau matematika merupakan mata pelajaran yang wajib diberikan kepada siswa sejak Sekolah Dasar hingga Sekolah Menengah Atas. Apabila kita ingin bersaing dengan negara lain maka perlu perubahan pola pembelajaran dan pola pendidikan terutama pada pelajaran matematika dengan memberikan perlakuan-perlakuan serta penekananpenekanan tertentu dalam pembelajaran. Salah satunya adalah kemampuan berpikir kreatif dan mempertimbangkan aspek afektif dalam diri siswa seperti halnya SelfEfficacy siswa [1].

Dalam kegiatan pembelajaran, siswa yang memiliki kemampuan berpikir kreatif dapat membantu siswa lainnya yang mengalami masalah dalam memahami materi pelajaran. Pengembangan kemampuan berpikir kreatif memang perlu dilakukan karena kemampuan ini merupakan salah satu kemampuan yang dikehendaki dunia kerja.Tidak diragukan lagi bahwa kemampuan berpikir kreatif juga menjadi penentu keunggulan suatu bangsa. Daya kompetitif suatu bangsa sangat ditentukan oleh kreativitas sumber daya manusianya. Pembelajaran matematika perlu dirancang sedemikian sehingga berpotensi mengembangkan kemampuan berpikir kreatif siswa. Pengembangan kemampuan berpikir kreatif perlu dilakukan seiring dengan pengembangan cara mengevaluasi atau cara mengukurnya. Pentingnya kreativitas dalam matematika dikemukakan oleh Bishop (dalam A. Mahmudin) [2] yang menyatakan bahwa seseorang memerlukan dua keterampilan berpikir matematis, yaitu berpikir kreatif yang sering diidentikkan dengan intuisi dan kemampuan berpikir analitik yang diidentikkan dengan kemampuan berpikir logis. Sementara Kiesswetter (dalam A. Mahmudin)[3] menyatakan bahwa kemampuan berpikir fleksibel yang merupakan salah satu aspek kemampuan berpikir kreatif merupakan kemampuan penting yang harus dimiliki siswa dalam menyelesaikan masalah matematika. Pendapat ini menegaskan eksistensi kemampuan berpikir kreatif matematis [4].

Di samping banyaknya penelitian dalam aspek kognitif, dalam 20 tahun terakhir ini aspek afektif mulai ditelaah para peneliti, antara lain Self-Efficacy (hampir identik dengan "kepercayaan diri") yang diperkirakan dapat meningkatkan kemampuan matematika siswa. SelfEfficacy melembagakan suatu komponen kunci di dalam teori kognitif sosial Bandura [5]. Membangun menandakan kepercayaan diri seseorang, mengenai kemampuannya untuk sukses melaksanakan suatu tugas. Itu ditemukan bahwa Self-Efficacy adalah suatu faktor penentu pilihan utama untuk pengembangan individu, ketekunan dalam menggunakan diberbagai kesulitan, dan pemikiran mempola dan reaksi-reaksi secara emosional yang mereka alami (Bandura)[6]. Self-Efficacy dapat dibangkitkan dari diri siswa melalui empat sumber, yaitu (1) Pengalaman otentik (authentic mastery experiences), (2) Pengalaman orang lain (vicarious experience), (3) Pendekatan sosial atau verbal (verbal persuasion), (4) Aspek psikologi (physiological affective states). 
Kemampuan Self-Efficacy ini juga dituntut dalam kurikulum matematika. Tuntutan pengembangan kemampuan Self-Efficacy yang tertulis dalam kurikulum metematika antara lain menyebutkan bahwa pelajaran matematika harus menanamkan sikap menghargai kegunaan matematika dalam kehidupan, yaitu memiliki rasa ingin tahu, perhatian, dan minat dalam mempelajari matematika, serta sikap ulet dan percaya diri, dan kemampuan komunikasi. Salah satu langkah yang bisa dilakukan oleh guru untuk meningkatkan kemampuan berpikir kreatif dan Self-Efficacy siswa adalah memberikan pembelajaran yang di dalamnya disajikan masalah-masalah terbukabaik proses maupun jawabannya sehingga lebih mengundang siswa untuk mengasah kemampuan berpikirnya. Diperlukan suatu pendekatan dalam menyampaikan pembelajaran yang dapat meningkatkan sikap siswa atau membuat siswa berpikir positif terutama pada pembelajaran matematika. Guru dapat menyajikan pembelajaran yang bernuansa pemecahan masalah dan berpandangan konstruktivisme sebagai salah satu upaya meningkatkan kemampuan berpikir kreatif matematis dan Self-Efficacy siswa. Pembelajaran yang seperti itu, diantaranya adalah pembelajaran matematika dengan pendekatan OpenEnded [7].

Kelebihan pembelajaran dengan Open-Ended terletak pada cara penyelesaiannya maupun jawabannya yang tidak tunggal dalam memecahkan masalah. Menurut Hudiono (dalam Lambertus)[8] "Pendekatan Open- Ended dalam pembelajaran matematika bertujuan menciptakan suasana pembelajaran bagi siswa memperoleh pengalaman baru melalui proses pembelajaran". Inti pembelajaran Open-Ended adalah membangun kegiatan interaktif antara matematika dan siswa sehingga mengundang siswa untuk menjawab permasalahan melalui berbagai strategi. Pemecahan masalah matematis tersebut merupakan salah satu unsur daya matematis tingkat tinggi yang menuntut kemampuan berpikir kreatif matematis. Pendekatan Open-Ended (Nuraini)[9] menjanjikan suatu kesempatan kepada siswa untuk menginvestigasi berbagai strategi dan cara yang diyakininya sesuai dengan kemampuan mengelaborasi. Tujuannya tiada lain adalah agar kemampuan berpikir matematika siswa dapat berkembang secara maksimal dan pada saat yang sama kegiatan-kegiatan kreatif dari setiap siswa terkomunikasikan melalui proses belajar mengajar. Guru mengemas pembelajaran sekaligus memanfaatkan kesempatan untuk mengembamgkan materi pembelajaran lebih lanjut yang sedikit banyak telah dikenal oleh siswa sendiri. Dengan cara demikian siswa akan benar- benar merasa berkepentingan dan termotivasi tinggi untuk menyelesaikan permasalahan sendiri.

\section{a. Kemampuan Berpikir Kreatif}

Berpikir kreatif memiliki peranan penting dalam berpikir tingkat tinggi, sebab kreativitas menentukan kuantitas kemungkinan solusi dari permasalahan yang dihadapi. Dalam berpikir tingkat tinggi, kemampuan mencari berbagai solusi merupakan modal utama. Kemampuan memikirkan berbagai kemungkinan ini dikenal sebagai kemampuan memprediksi. Dalam istilah lain kemampuan seperti ini disebut memiliki kemampuan berpikir secara luas atau menyebar.

Kemampuan berpikir kreatif sangat membantu dalam mengembangkan berpikir matematika tingkat tinggi. Kemampuan berpikir kreatif berperan penting dalam setiap langkah pengembangan berpikir matematika tingkat tinggi tersebut. Kemampuan berpikir kreatif membantu kelancaran pengembangan berpikir. kemampuan berpikir kreatif siswa akan dipengaruhi oleh beberapa aspek berikut (Supriadi)[10]: pemahaman siswa (understanding), intuisi (intuition), cakrawala atau keluasan wawasan (insight), serta kemampuan mengeneralisasikan (generalization). Pemahaman merupakan modal awal dalam memecahkan masalah. Oleh karena 
itu pemahaman menjadi modal dalam berpikir kreatif. Intuisi dan keluasan wawasan sangat membantu dalam proses berpikir kreatif. Wawasan yang luas akan memberikan banyak scaffolding dalam pemecahan masalah, demikian pula dalam proses kreatif. Kemampuan menggeneralisasikan akan membantu siswa pada saat penegasan hasil kreasi. Hasil generalisasi akan mampu mendukung pertanggung jawaban siswa secara ilmiah. Indikator Berpikir Kreatif adalah sebagai berikut: Guilford (dalam Reni)[11] dengan analisisnya menemukan ada lima ciri-ciri berpikir kreatif: pertama, kelancaran (fluency) adalah kemampuan untuk memproduksi banyak gagasan. Kedua, keluwesan (feksibility) adalah kemampuan untuk mengajukan macam-macam pendekatan dan/atau jalan pemecahan terhadap masalah. Ketiga, keaslian (originality) adalah kemampuan untuk melahirkan gagasan-gagasan asli sebagai hasil pemikiran sendiri. Keempat, penguraian (elaborasi) adalah kemampuan untuk menguraikan sesuatu secara terperinci. Kelima, perumusan kembali (redefininition) adalah kemampuan untuk mengkaji/menilik kembalisuatu persoalan melalui cara dan perspektif yang berbeda dengan apa yang sudah lazim.

\section{b. Kemampuan Self-Efficacy}

Dari berbagai pendapat para ahli, self-efficacy pada prakteknya sinonim dengan "keyakinan diri", meskipun "keyakinan diri" adalah suatu istilah yang non-deskriptif (Bandura) [12], yang merujuk pada kekuatan keyakinan, misalnya seseorang dapat sangat percaya diri, tetapi akhirnya gagal. Selfefficacy didefinisikan sebagai pertimbangan seseorang tentang kemampuan dirinya untuk mencapai tingkatan kinerja (performansi) yang diinginkan atau ditentukan, yang akan mempengaruhi tindakan selanjutnya.

Self-efficacy terhadap matematika merupakan hal penting yang harus ditanamkan pada anak sejak dini.Ada korelasi yang kuat antara hasil tes matematika yang diharapkan oleh siswa dan keyakinan siswa itu tentang kemampuannya. Sebagaimana Setiadi [13] mengatakan bahwa: (1) Siswa yang merasa "lemah dalam matematika" percaya bahwa keberhasilan dalam tes matematika merupakan "kebetulan" atau "nasib baik", sedangkan kegagalan (hasil rendah) dalam tes matematika merupakan akibat dari kekurangmampuan. Sementara itu, murid yang merasa dirinya "kuat dalam matematika" percaya bahwa keberhasilan dalam tes matematika adalah hasil dari kemampuannya sendiri, (2) Makin "kuat dalam matematika" siswa makin kurang percaya bahwa „kebanyakan isi pelajaran matematika merupakan hafalan", dan (3) Makin „kuat dalam matematika" siswa makin kurang percaya bahwa „keberhasilan dalam tes matematika tergantung pada kekuatan menghafal".

\subsection{Pembelajaran OpenEnded}

Pendekatan Open- Ended mulai dikembangkan di Jepang pada tahun 70 an, dan semenjak itu guru-guru di Jepang menggunakan pendekatan ini dalam pembelajaran matematika di sekolah. Pendekatan Open-Ended adalah pendekatan pembelajaran yang menyajikan suatu permasalahan yang memiliki lebih dari satu jawaban atau metode penyelesaian. Pendekatan OpenEnded menjanjikan suatu kesempatan kepada siswa untuk menginvestigasi berbagai cara yang diyakininya sesuai dengan kemampuan mengelaborasi permasalahan (Yunita Sari)[14] Masalah yang diberikan pada pendekatan OpenEnded adalah masalah yang bersifat terbuka atau masalah tidak lengkap atau dapat disebut juga masalah yang tidak rutin. Melalui pendekatan Open-Ended siswa dituntut untuk melakukan observasi, bertanya, menentukan relasi menampilkan alasan-alasan dan menarik kesimpulan. Oleh karena itu, pendekatan Open-Ended memiliki banyak kesesuaian dengan komponen berpikir matematis. Pembelajaran dengan menggunakan pendekatan Open-Ended lebih bermakna jika kegiatan siswa untuk berpikir dalam membuat proses pemecahan masalah sesuai kemampuan sikap dan minatnya sehingga pada akhirnya akan membentuk inteligensi matematika. Pembelajaran dengan Pendekatan Open-Ended diawali dengan memberikan masalah terbuka kepada siswa. Kegiatan pembelajaran harus mengarah dan membawa siswa dalam menjawab masalah dengan banyak 
cara serta mungkin juga dengan banyak jawaban (yang benar) sehingga merangsang kemampuan intelektual dan pengalaman siswa dalam proses menemukan sesuatu yang baru. Siswa yang dihadapkan dengan masalah OpenEnded tujuan utamanya bukan untuk mendapatkan jawaban tetapi lebih menekankan pada cara bagaimana sampai pada suatu jawaban. Dengan demikian bukan hanya satu pendekatan atau metode dalam mendapatkan jawaban namun beberapa atau banyak. Pendekatan Open-Ended menjanjikan suatu kesempatan kepada siswa untuk menginvestigasi berbagai strategi dan cara yang diyakininya sesuai dengan kemampuannya mengelaborasi permasalahan. Tujuannya adalah agar kemampuan berpikir matematis siswa dapat berkembang secara maksimal dan pada saat yang sama kegiatan-kegiatan kreatif dari setiap siswa terkomunikasikan melalui proses pembelajaran.
Penelitian ini merupakan penelitian eksperimen semu (quasi experiment). Peneliti melakukan pengelompokkan sampel berdasarkan kelas yang telah terbentuk sebelumnya atau kelas yang sudah ada. Sehingga penelitian ini menggunakan metode eksperimen semu dengan kelas yang sudah ada tanpa membentuk kelas baru. Penelitian ini bertujuan menelaah tentang kemampuan berpikir kreatif dan Self-Efficacy siswa yang dipengaruhi oleh pembelajaran yaitu pembelajaran matematika dengan pendekatan OpenEnded dan pembelajaran konvensional.

\section{Disain Penelitian}

Penelitian ini adalah penelitian quasi eksperimen dengan menggunakan dua kelompok. Kelompok yang pertama yaitu kelompok eksperimen dan yang kedua kelompok kontrol. Kelas eksperimen diberi perlakuan dengan pendekatan pembelajaran Open-Ended dan kelas kontrol diberi perlakuan dengan pembelajaran konvensional.

\section{METODE PENELITIAN}

\begin{tabular}{|c|c|c|c|}
\hline Kelompok Perlakuan & $\begin{array}{c}\text { Pre- } \\
\text { test }\end{array}$ & Perlakuan & Post-test \\
\hline $\begin{array}{c}\text { Pendekatan Open-Ended } \\
\text { (Eksperimen) }\end{array}$ & $\mathrm{O}$ & $\mathrm{X}_{1}$ & $\mathrm{O}$ \\
\hline $\begin{array}{c}\text { Pembelajaran Konvensional } \\
\text { (Kontrol) }\end{array}$ & $\mathrm{O}$ & $\mathrm{X}_{2}$ & $\mathrm{O}$ \\
\hline
\end{tabular}

\section{HASIL DAN PEMBAHASAN}

1. Hasil Tes Kemampuan Awal Matematika (KAM)

Perhitungan Uji Normalitas Data KAM dijelaskan pada tabel berikut:

Dalam tabel dijelaskan bahwa nilai sig. untuk setiap kelompok > dari 0,05 maka Ho diterima.

\begin{tabular}{|c|c|c|c|}
\hline \multirow{2}{*}{ Kelompok } & \multicolumn{3}{|c|}{ Kolmogorov-Smirnov } \\
\cline { 2 - 4 } & $\mathbf{N}$ & Sig. & A \\
\hline PMO & 89 & 0,064 & 0,05 \\
\hline PMK & 89 & 0,061 & 0,05 \\
\hline
\end{tabular}

Perhitungan Uji Homogenitas Data KAM untuk setiap kelompok > dari 0,05 maka dijelaskan pada tabel berikut: Ho diterima.

Dalam tabel dijelaskan bahwa nilai sig.

\begin{tabular}{|c|c|c|c|c|}
\hline $\mathrm{H}$ & Levene Statistic & df1 & df2 & Sig. \\
\hline a & 0,577 & 1 & 176 & 0,448 \\
\hline
\end{tabular}


Dalam tabel dijelaskan bahwa nilai diterima.

sig. > dari 0,05 maka hipotesis nol

\begin{tabular}{|c|r|r|r|r|r|}
\hline & Sum of Squares & \multicolumn{1}{|c|}{ df } & Mean Square & F & Sig. \\
\hline Between Groups & 2.972 & 1 & 2.972 & .464 & .497 \\
\hline Within Groups & 1126.517 & 176 & 6.401 & & \\
\hline Total & 1129.489 & 177 & & & \\
\hline
\end{tabular}

2. Hasil Tes Kemampuan Berpikir Kreatif Perhitungan Uji Normalitas Indeks

\begin{tabular}{|c|c|}
\hline Kelompok & \\
& \\
\cline { 2 - 2 } & $\mathbf{N}$ \\
\hline PMO & 89 \\
\hline PMK & 89 \\
\hline
\end{tabular}

Dalam tabel dijelaskan bahwa pada kelas quasi eksperimen diperoleh nilai yaitu $0,938>0,05$ sehingga $H_{0}$ diterima dan $H_{a}$ ditolak. Demikian juga pada kelas kontrol diperoleh nilai yaitu $0,995>0,05$ sehingga $H_{0}$ diterima $H_{a}$ ditolak. Dengan demikian, data yang diperoleh dari indeks
Gain pada kedua pembelajaran dijelaskan pada tabel berikut:

\section{Kolmogorov-Smirnov}

Sig.

0,938

0,995

A

gain hasil tes kemampuan berpikir kreatif pada kelas eksperimen dan kelas kontrol berdistribusi normal.

Pengujian Homogenitas Indeks Gain pada kedua pembelajaran dijelaskan pada tabel berikut:

\begin{tabular}{|c|c|c|c|}
\hline Levene Statistic & df1 & df2 & Sig. \\
\hline 2,648 & 1 & 176 & 0,105 \\
\hline
\end{tabular}

Dalam tabel dijelaskan bahwa pada kelompok data gain kemampuan berpikir kreatif lebih besar dari 0,05, yaitu 0,105 > 0,05 sehingga hipotesis nol diterima. Ini

artinya bahwa, varians kedua kelompok pendekatan tersebut adalah homogen.

Rangkuman Uji Anava Dua Jalur dijelaskan dalam tabel dibawah ini

\begin{tabular}{|c|c|c|c|c|c|}
\hline Source & $\begin{array}{c}\text { Type III Sum } \\
\text { of Squares }\end{array}$ & df & Mean Square & F & Sig. \\
\hline Corrected Model & $613.975^{a}$ & 5 & 122.795 & 11.750 & .000 \\
Intercept & 2064.075 & 1 & 2064.075 & 197.501 & .000 \\
KELOMPOK & 316.189 & 1 & 316.189 & 30.254 & .000 \\
KEMAMPUAN & 127.181 & 2 & 63.590 & 6.085 & .003 \\
KELOMPOK * & 13.796 & 2 & 6.898 & .660 & .518 \\
KEMAMPUAN & 1797.570 & 172 & 10.451 & & \\
Error & 5087.815 & 178 & & & \\
Total & 2411.545 & 177 & & & \\
Corrected Total & & & &
\end{tabular}

3. Hasil Tes Kemampuan Self-Efficacy Perhitungan Uji Normalitas Indeks

\begin{tabular}{|c|c|}
\hline Kelompok & \\
\cline { 2 - 2 } & $\mathbf{N}$ \\
\hline PMO & 89 \\
\hline PMK & 89 \\
\hline
\end{tabular}

Dalam tabel dijelaskan bahwa pada kelas quasi eksperimen diperoleh nilai yaitu $1,038>0,05$ sehingga $H_{0}$ diterima dan $H_{a}$ ditolak. Demikian juga pada kelas kontrol diperoleh nilai yaitu yaitu $1,119>0,05$
Gain pada kedua pembelajaran dijelaskan pada tabel berikut:

\section{Kolmogorov-Smirnov}

\begin{tabular}{l|r} 
Sig. & A \\
\hline 1,038 & 0,05 \\
\hline 1,119 & 0,05 \\
\hline
\end{tabular}

sehingga $H_{0}$ diterima $H_{a}$ ditolak. Dengan demikian, data yang diperoleh dari indeks gain hasil pengisian skala Self-Efficacy pada kelas eksperimen dan kelas kontrol berdistribusi normal. 
Pengujian Homogenitas Indeks Gain pada kedua pembelajaran dijelaskan pada tabel

berikut:

\begin{tabular}{|c|c|c|c|}
\hline Levene Statistic & df1 & df2 & Sig. \\
\hline 3,554 & 1 & 176 & 0,061 \\
\hline
\end{tabular}

Dalam tabel dijelaskan bahwa pada 0,05 sehingga hipotesis nol diterima. Ini kelompok data Indeks gain hasil skala SelfEfficacy lebih besar dari 0,05, yaitu 0,061 > artinya bahwa, varians kedua kelompok pendekatan tersebut adalah homogen.

4. Interaksi antara Faktor Pendekatan Pembelajaran dengan Faktor Kemampuan Awal Matematika Siswa Terhadap Peningkatan Kemampuan Berpikir Kreatif Siswa.

\begin{tabular}{|c|c|c|c|c|c|}
\hline Source & $\begin{array}{c}\text { Type III Sum } \\
\text { of Squares }\end{array}$ & df & Mean Square & F & Sig. \\
\hline Corrected Model & $613.975^{\mathrm{a}}$ & 5 & 122.795 & 11.750 & .000 \\
Intercept & 2064.075 & 1 & 2064.075 & 197.501 & .000 \\
KELOMPOK & 316.189 & 1 & 316.189 & 30.254 & .000 \\
KEMAMPUAN & 127.181 & 2 & 63.590 & 6.085 & .003 \\
KELOMPOK* & 13.796 & 2 & 6.898 & .660 & .518 \\
KEMAMPUAN & 1797.570 & 172 & 10.451 & & \\
Error & 5087.815 & 178 & & & \\
Total & 2411.545 & 177 & & & \\
Corrected Total & &
\end{tabular}

Dari tabel dijelaskan bahwa nilai sig. 0,518 $>0,05$ sehingga Ho diterima, maka tidak

5. Interaksi antara Faktor Pendekatan terdapat interaksi.

Pembelajaran dengan Faktor

Kemampuan Awal Matematika Siswa terhadap Peningkatan Self-Efficacy Siswa

Rangkuman Uji Anava Dua

\begin{tabular}{|c|c|c|c|c|c|}
\hline Source & $\begin{array}{c}\text { Type III Sum of } \\
\text { Squares }\end{array}$ & df & $\begin{array}{c}\text { Mean } \\
\text { Square }\end{array}$ & F & Sig. \\
\hline Corrected Model & $813.864^{\mathrm{a}}$ & 5 & 162.773 & 1.311 & .262 \\
Intercept & 8023.325 & 1 & 8023.325 & 64.609 & .000 \\
KELOMPOK & 546.413 & 1 & 546.413 & 4.400 & .037 \\
KEMAMPUAN & 18.867 & 2 & 9.433 & .076 & .927 \\
KELOMPOK* KEMAMPUAN & 2.458 & 2 & 1.229 & .010 & .990 \\
Error & 21359.591 & 172 & 124.184 & & \\
Total & 32993.271 & 178 & & & \\
Corrected Total & 22173.456 & 177 & & & \\
\hline
\end{tabular}

Dari tabel dijelaskan bahwa nilai sig. 0,990 $>0,05$ sehingga Ho diterima, maka tidak terdapat interaksi.

\section{KESIMPULAN}

Berdasarkan hasil pembahasan penelitian, diperoleh bahwa peningkatan kemampuan berpikir kreatif matematis siswa yang diajar menggunakan pembelajaran matematika dengan pendekatan Open-Ended lebih baik daripada yang diajar dengan pembelajaran konvensional. Berdasarkan hasil penelitian dan pembahasan, diperoleh bahwa peningkatan Self-Efficacy siswa yang diajar menggunakan pembelajaran matematika dengan pendekatan Open-Ended lebih baik daripada yang diajar dengan pembelajaran konvensional. Berdasarkan hasil penelitian dan pembahasan, diperoleh bahwa tidak terdapat interaksi antara pendekatan pembelajaran dan kemampuan awal matematika siswa terhadap peningkatan kemampuan berpikir kreatif matematis siswa. Berdasarkan hasil penelitian dan pembahasan, diperoleh bahwa tidak terdapat interaksi antara pendekatan pembelajaran dan kemampuan awal matematika terhadap peningkatan SelfEfficacy siswa. 


\section{DAFTAR PUSTAKA}

[1]Bandura.1997. Tiga Dimensi self-efficacy. (Online),

(http://repository.usu.ac.id/bitstrea $\mathrm{m} / 123456789 / 26802 / 4 /$ Chapter\%2 0ll.pdf, diakses 5 Maret 2012)

[2]Mahmudin, Ali. 2010. Mengukur Kemampuan Berpikir Kreatif Matematis. Makalah Konfrensi Nasional Matematika XV. UNIMA Manado 30 Juni-3 Juli 2010. Yogyakarta: Universitas Negeri Yogyakarta. Diakses tanggal 25 Agustus 2013.

[3]Mahmudin, Ali. 2010. Mengukur Kemampuan Berpikir Kreatif Matematis. Makalah Konfrensi Nasional Matematika XV. UNIMA Manado 30 Juni-3 Juli $2010 . \quad$ Yogyakarta: Universitas Negeri Yogyakarta. Diakses tanggal 25 Agustus 2013.

[4]Khairina. 2012. Penerapan Pendekatan Pembelajaran Open Ended untuk Meningkatkan Kemampuan Berfikir Kreatif dan Penalaran Matematis Siswa Sekolah Menengah Atas. Tidak diterbitkan: Medan: PPs UNIMED.

[5].1997.

Faktor mempengaruhi self-efficacy (Online), (http://psychemate.blogspot.com/2 007/12/self-efficacy.html, diakses 5 Maret 2012)

[6]1997. Faktor mempengaruhi yang (Online), (http://psychemate.blogspot.com/2 007/12/self-efficacy.html, diakses 5 Maret 2012)

[7]Lambertus, dkk. 2013. Penerapan Pendekatan Opend-Ended untuk meningkatkan kemampuan Berpikir Kreatif Matematik Siswa SMP.
Jurnal Pendidikan Matematika Volume 4 Nomor 1 Januari 2013. Diakses tanggal 30 Desember 2013

[8]Lambertus, dkk. 2013. Penerapan Pendekatan Opend-Ended untuk meningkatkan kemampuan Berpikir Kreatif Matematik Siswa SMP. Jurnal Pendidikan Matematika Volume 4 Nomor 1 Januari 2013. Diakses tanggal 30 Desember 2013

[9]Nuraini. 2012. Pengaruh Penerapan Pendekatan Open-Ended terhadap Tingkat Kreativitas, Kemampuan Pemecahan Masalah Matematika, dan Sikap Siswa SMP di Aek Kanopan. PPs UNIMED.

[10]Supriadi, Dedi. 1994. Kreativitas, Kebudayaan, dan Pengembangan IPTEK. Bandung: Alfabeta.

[11] Reni, dkk. 2001. Kreativitas. Jakarta: Gramedia

[12]Setiadi, R. 2010. Self - Efficacy In Indonesia Literacy Teaching Contex : A Theoretical and Empirical Perspective. Bandung: Rizqi Press

[13]Setiadi, R. 2010. Self - Efficacy In Indonesia Literacy Teaching Contex : A Theoretical and Empirical Perspective. Bandung: Rizqi Press

[14]Sari, Yunita, dkk. 2013. Penerapan Pendekatan Open-Ended dalam Pembelajaran Matematika untuk Meningkatkan Kemampuan Berpikir Matematis Siswa Ditinjau dari Respon Siswa terhadap Pembelajaran Tahun Ajaran 2011/2012. Jurnal Pendidikan Matematika Solusi Vol.1 No.1 Maret 2013. Diakses tanggal 30 Desember2013 